\title{
Life Forms: A Keyword Entry
}

\section{Citation}

Helmreich, Stefan, and Sophia Roosth. 2010. Life forms: A keyword entry. Representations 112, no. 1: 27-53.

\section{Published Version}

doi:10.1525/rep.2010.112.1.27

\section{Permanent link}

http://nrs.harvard.edu/urn-3:HUL.InstRepos:11639530

\section{Terms of Use}

This article was downloaded from Harvard University's DASH repository, and is made available under the terms and conditions applicable to Other Posted Material, as set forth at http:// nrs.harvard.edu/urn-3:HUL.InstRepos:dash.current.terms-of-use\#LAA

\section{Share Your Story}

The Harvard community has made this article openly available.

Please share how this access benefits you. Submit a story.

Accessibility 


\section{Life Forms: A Keyword Entry}

IN A 2007 REPORT JOINTLY ISSUED by the United States National Research Council's Committee on the Limits of Organic Life in Planetary Systems and Committee on the Origins and Evolution of Life, biologists interested in the possibility of life on other planets speculate that living systems might employ ammonia, sulfuric acid, or methane as a solvent in the way life on Earth uses water. ${ }^{1}$ Perhaps just as remarkable as the project of chemical conjecture delivered by this report, however, is the document's opening inscription: Dedicated to Non-Human-Like Life Forms, Wherever They Are. ${ }^{2}$ Leaving aside the authors' probable intention that "non-human-like" should rather read "unknown" or "extraterrestrial," what captures our attention in this address is its most workaday term: life forms. How did life come to have a form? More modestly and narrowly: where did the term life form come from? And what has life form come to mean in the contemporary moment, when it is possible to use the term to refer to as-yet conjectural manifestations, manifestations that may redefine the very referent of life itself?

In The Life of Forms in Art, art historian Henri Focillon writes, "Form is surrounded by a certain aura: although it is our most strict definition of space, it also suggests to us the existence of other forms." Inspired by Focillon, we ask: how does the concept of life form operate to suggest the existence of other life forms? We argue that life form has, since its earliest nineteenth-century enunciations, pointed to a space of possibility within which life might take shape. Exactly how that space is understood and theorized has transformed as the term has traveled into the present. We suggest that life form has moved from its origins as a term referring to abstract, idealized, aesthetic possibilities through reference to biogeographic and evolutionary possibilities to, today, conjectural and future possibilities.

\footnotetext{
A B S T RACT We deliver a "keyword" account of the term life form as it has been used in natural philosophy and biology over the last two hundred years, beginning with its appearance in German as Lebensform. We argue that life form has, since its earliest enunciations, pointed to a space of possibility within which life might take shape, but that the way that space is imagined and theorized in biology has transformed substantially; life form originated as a term referring to idealized, aesthetic possibilities, then transformed to describe biogeographic and evolutionary potentialities, and today, in the age of synthetic biology and astrobiology, has come to signal conjectural and future possibilities. / REPRESENTATIONS 112. Fall 2010 (C) The Regents of the University of California. ISSN 0734-6018, electronic ISSN 1533-855X, pages 27-53. All rights reserved. Direct requests for permission to photocopy or reproduce article content to the University of California Press at http://www. ucpressjournals.com/reprintinfo.asp. DOI:10.1525/rep.2010.112.1.27.
} 
To put this in logical terms, we track a move from deductive to inductive and then abductive reasoning. We begin with deductive reasoning, the drawing of conclusions from known principles (for example, when, as with German Romantic biologists, plant and animal forms were imagined to be deducible from archetypical aesthetic patterns present in nature, neo-Platonically conceived). Next we consider inductive reasoning, which unfolds by inference from particulars toward general conclusions (for example, when, as with Darwin, descriptions of organic variation were leveraged into hypotheses about the shaping of that variation by such forces as natural selection). And last we discuss abductive reasoning, which derives from premises that may or may not materialize in the future (for example, when, as with astrobiologists, life is posited as a coherent conceptual category even in advance of discovering all possible cases). Semiotician Charles Sanders Peirce described abduction as "a method of forming a general prediction without any positive assurance that it will succeed either in the special case or usually, its justification being that it is the only possible hope of regulating our future conduct rationally." ${ }^{4}$ In its abductive articulation, life form has come to be a future-oriented, even hopeful, term-a term that in some instances underwrites a constructive approach to vitality (for example, when, as with today's synthetic biologists, "life" becomes a conceptual category that may be explored through its de novo construction in the laboratory).

\section{Capacious Doctrines: Warranting a Keyword Approach}

The approach we take to mapping this historical transformation is inspired by Raymond Williams's 1976 Keywords, in which Williams offers histories of key words in social theory, detailing the shifting, contested meanings of such terms as culture, nature, and ideology. Williams described his enterprise as:

an inquiry into a vocabulary. . . . Every word which I have included has at some time, in the course of some argument, virtually forced itself on my attention because the problems of its meanings seemed to me inextricably bound up with the problems it was being used to discuss. ${ }^{5}$

We intend, following Williams, this keyword entry to be an examination of one term-life form - that has forced itself on our attentions in the course of our inquiries into the social and epistemological practices of the contemporary biosciences. ${ }^{6}$ Our account cannot be exhaustive, nor can it fully attend to protohistories of life form, following, for example, how life and form circulated independently of one another prior to their amalgamation in nineteenthcentury German as Lebensform. ${ }^{7}$ As Williams suggests, "Any account is bound to be incomplete, in a serious sense, just as it is bound to be selective." 8 
While tracking words and concepts may not be the same task, guiding Williams's project is his conviction that language serves as a crucible in which ideas take shape: in words, "meanings are offered, felt for, tested, confirmed, qualified, changed." Intellectual historians and literary critics such as Quentin Skinner and William Empson have taken issue with two aspects of Williams's method: his yoking of concepts to words and his implication that language might not only express concepts but also shape them. ${ }^{10}$ Even so, Skinner admits that "the surest sign that a group or society has entered into the self-conscious possession of a new concept is that a corresponding vocabulary will be developed, a vocabulary which can then be used to pick out and discuss the concept with consistency." "11 Our aim is to use life form, the term, as an index through which to gauge what "life," the concept, has meant at different moments. We submit, following Williams, that changes in the manner in which life form is used may signal, even propel, conceptual changes. ${ }^{12}$

We also take as a model Evelyn Fox Keller and Elisabeth Lloyd's 1992 Keywords in Evolutionary Biology, which undertakes a similar project to Williams's for terms such as adaptation, natural selection, and fitness. Keller and Lloyd catalog the utility of the keyword approach to historians and philosophers of science. Keywords, for them, serve as:

indicators of patterns of scientific meaning and of changes over time in the ways that particular scientific meanings have been structured. Attending to the multiple meanings of key terms provides a lens through which it is possible not only to understand better what is at issue in particular scientific debates but also to scrutinize the very structure of the arguments under debate. Such a lens enables an exploration of the historically evolving field of meanings from which these arguments draw and on which they depend. ${ }^{13}$

In line with Keller and Lloyd's take on key terms in science, we hold that the "multiple meanings" of life form are fundamental to its prevalence in the life sciences: the term's elasticity, its capacity to gesture toward senses and doctrines beyond itself, allows it to operate as a frame through which biological thinking can be worked out. If, as William Empson explains, a keyword is a "compacted doctrine," a form that compresses multiple, often divergent, meanings, then life form may be considered to embody a "capacious doctrine," a term with a constitutive incompleteness, ready for use in working out fresh problems. ${ }^{14}$ If, as Alan Durant has argued in his 2006 defense of Williams's approach, the word keyword in the age of Google often summons up the sense of a "search" word, life form interestingly turns out to function as just that kind of scouting operator. ${ }^{15}$

We have selected our sources to draw attention to the curious history of a term that, while now so unassuming as to be the rhetorical equivalent of wallpaper, overlooked and unquestioned, bears the residues of previous glosses. 
More than simply an exercise in etymology, however, this venture is an attempt to unearth how a concept undergoes multiple recalibrations and repurposings within shifting epistemological frames. Life form transforms as it is articulated in the registers of natural history and evolutionary biology and, most recently, in dialogue with fields such as computer science and engineering. Rather than functioning as an easy answer to a conceptual problem, or set of problems, posed by different schools and eras of biological thinking, life form has, over the last two centuries, helped articulate new problems in biology, which have been addressed deductively, inductively, and abductively.

Our keyword entry for life form (and its cousin, life-form) begins with the Oxford English Dictionary, which provides the following for life-form:

1. Biol. A habit or vegetative form exhibited by any particular plant or which characterizes a group of plants.

and

2. A living creature; any kind of living thing. ${ }^{16}$

The "vegetative form" to which the first $O E D$ definition refers is, in a rider to that entry, explicated with reference to the 1903 classificatory work of the Danish botanist Christen Raunkiær: "Various life-form classifications have been proposed. That of C. Raunkiær (or a modification of his system) based upon the position of the buds relative to the soil surface during the unfavourable season is the one generally employed." This classification system, aimed at sorting out plants, offers as examples of life-forms such types as therophtyes (seed-bearing annuals) and hydrophytes (aquatic plants, like water-lilies). Form here follows from the habits of the plant (that is, its manner of growth and appearance). But form also immediately points to matters of classification and representation. These two notions of form-as emergent with embodiment and as a tool of classification-coil around each other in nineteenth-century discussions about how an organism's morphology might be affected by its surrounding environment and about how this might in turn guide possible classificatory schemes. This dual sense of form, as we will see, shapes deductive, inductive, and abductive approaches to the question of how life takes form.

The $O E D$ 's second definition points toward particular instances or embodiments of life but also signals the capaciousness of the concept of life-form as such; in "any kind of living thing," the emphasis is on any.

But we must dig deeper into etymology, biology, and the history of natural history to track lineages to do with representation and classification as well as with the relation of organismic form to environment. ${ }^{17}$ Life-form enters English from the German Lebensform, referring, according to the OED's first 
usage quotation from 1899, to "groups of similar adaptational form [that] by no means coincide with natural families or groups of species." From whence did this meaning arrive?

\section{Lebensformen: The Deduction of Living Form}

According to the Deutsches Wörterbuch of Jakob and Wilhelm Grimm, Lebensform appears in German in 1838 in the Jenaer Literatur-Zeitung:

LEBENSFORM, $f:$ die physische beschaffenheit der weltkörper und die auf denselben möglichen lebensformen. Jenaer litt.-zeitung 1838, no. 179 s. 468 ("the physical properties of heavenly bodies and the life forms possible upon them").

This extract suggests that physical circumstances might delimit the space in which life forms manifest. ${ }^{18}$ A quite different framing of Lebensform appears in German physiologist Karl Friedrich Burdach's Die Physiologie als Erfahrungswissenschaft (Physiology as a Science of Practical Experience), from 1826 to 1840, in which Burdach writes, "The occurrence of new life forms is therefore not external, but is determined by inner life forces and grounded in life itself [Das Erscheinen neuer Lebensformen ist demnach kein äußerliches Hinzutreten, sondern von innen her bestimmt und im Leben selbst begründet]. ${ }^{, 19}$ Where the 1838 Jenaer Literatur-Zeitung quotation situates life forms in external physical conditions, Burdach's phrasing posits life forms as self-organizing according to an inner principle. ${ }^{20}$ Burdach sought to render visible this principle by training his students at the Anatomical Institute in Königsberg in Goethe's disciplined perception and morphology such that "living forms and their interconnections become evident in his [the student's] soul." ${ }^{21}$ Such vitalism, which first appeared around 1790, was one current in the German biology of the Romantic period. ${ }^{22}$

According to Timothy Lenoir, German materialist vitalism—a vitalism that saw life as sited in a material world, even as such vitality could not be collapsed into sheer mechanism - was also tuned to aesthetic considerations, leaning strongly on Immanuel Kant's conception of form. ${ }^{23}$ Kant's 1790 theory of aesthetic judgment understood the pleasure taken in observing a living thing to stem in part from imagining a purposiveness in its form. ${ }^{24}$ Johannes Müller (1801-1858), a physiologist and anatomist whose students included Hermann Ludwig Ferdinand von Helmholtz, Ernst Haeckel, and Louis Agassiz, used Lebensform in the title of a piece dated from 1834 to 1840, "Schlussbemerkungen über die Entwickelungsvariationen der tierischen and menschlichen Lebensformen auf der Erde" (Concluding Remarks on the Variations of Development in Animal and Human Life Forms on Earth), and Lenoir writes that "we learn from Helmholtz's correspondence that in order to understand 
Johannes Müller's lectures fully his spare moments had to be filled with reading Kant." ${ }^{25}$ Müller's conception of Lebensform was, to borrow Lenoir's coinage, "teleo-mechanist," characterized by a conviction that biological systems behaved mechanically and could be subjected to analytic tools developed in chemistry and physics, even as teleological principles might still be applied effectively where mechanistic accounts failed. Within this Kantian formulation, Lebensform was something that informed itself. Evelyn Fox Keller describes the Kantian organism as "a bounded body capable not only of self-regulation, self-steering, but also, and perhaps most important, of self-formation and selfgeneration; it is both an organized and a self-organizing being." 26

Johann Wolfgang von Goethe's morphology, inspired by and in dialogue with Kant, was an allied inspiration for German natural scientists, and was animated by a demand to use disciplined perception, at once empirical and aesthetic, to uncover the laws behind pure forms-what Goethe called Urformen. Such disciplined perception would permit a view of plant and animal forms as "derivations from an ideal type." ${ }^{27}$ Goethe sought, argues Joan Steigerwald, to arrive at "objective knowledge of nature by discerning the ideal archetypes giving necessity to the transformation of form." ${ }^{28}$ His colleague and sometime competitor Johann Christoph Friedrich von Schiller put front and center the deductive ethos that might motivate such an approach, arguing for a practice in which one would "start from abstract a priori principles, and deduce laws that are then to be demonstrated in the particular." 29

Lebensform thus bears an inheritance from Kant and Goethe (though this exact word was used by neither) in which form is aesthetic, self-determining, and teleological, as well as (generously assuming sufficient knowledge of the mechanism of its formation) deductively predictable (even if the favored apprehensional approach was often a combination of the intuitive and empirical). For many thinkers, the address from which such form was ultimately derived was left open; it might be in some numinous world soul or latent in Newtonian nature. ${ }^{30}$ This open-endedness, as we will see, remains a defining quality of life form, contributing to its continuing theoretical persuasiveness and semantic potency.

The focus on the aesthetics of life comes in the nineteenth century into tension with attention to how Lebensformen might emerge from organisms' habits and habitation. Lebensform appeared in an 1836 article by anatomist Theodor Bischoff in the Archiv fur Anatomie, Physiologie, und Wissenschaftliche Medicin, a journal edited by Müller. In this article, which concerns the structure of crocodile hearts, Bischoff wrote: "This strange imperfection of hematopoiesis [blood formation], which in the class of amphibians is caused by forms of blood circulation, must have a direct relation to their whole life form [Lebensform], and is probably related a great deal to their habitation in 
various media, in air and in water, as Professor Weber has explained in detail." ${ }^{31}$ Lebensform does double duty in this quotation: it refers to amphibianness as a general category, but it also points toward the relation of an organism to its environment.

That relation-of habit, habitation, and medium to the poiesis of the organism-becomes important in refinements of Lebensform, in which form is not simply a manifestation of an aesthetic impulse, but takes shape with respect to material circumstances. The central figure here is naturalist Alexander von Humboldt.

Alexander von Humboldt was influenced by the scholarship of his older brother, Wilhelm, a philosopher close to Goethe and Schiller. Wilhelm von Humboldt's articulation of Lebensform, in a historical philology lecture at the Akademie der Wissenschaften zu Berlin in 1824, had it as synonymous with custom: "Yet the common parlance includes (admittedly in one life form less than another) the whole population, and what has influenced one part, will be acquired collaterally by all [Denn die gemeinschaftliche Rede umschlingt doch (freilich in einer Lebensform weniger als in der andern) das ganze Volk, und was auf sie bei Einzelnen gewirkt ist, geht doch mittelbar auf Alle über]." "32 Lebensform was here used in a sense best translated as "form of life" or "way of life" (that is, custom or culture). ${ }^{33}$

Alexander von Humboldt generalized notions of Lebensform as custom or habit to the organic world. For him, humans and other animals were influenced by their physical environments in a fashion similar to plants: "A savage's state is primarily modified by the Nature of the climate and soil he inhabits. It is these modifications alone that distinguish the first inhabitants of Greece from shepherd Bedouins, and from Canadian Indians." ${ }^{34}$ For plants, as historian Robert Richards writes, Humboldt "regarded the different species and subspecies of plants as playing variations on . . constant themes. The same types, he thought, would be found in similar environmental conditions (for instance, of temperature, elevation, and moisture) across the globe." "At the same time, Humboldt did not abandon aesthetic commitments: "The discrimination of form, according to Humboldt, is an aesthetic task, not a classification done according to the usual criteria of botanical systems, such as that of Linnaeus. Rather, we must be guided by the painterly eye, which highlights the distribution of leaves, the forms of stems and branches." ${ }^{36}$ Humboldt brought into play the habitual, environmental conditioning of form, pulling aesthetic abstractions down to earth, beginning a shift from deductive to inductive thinking about life forms. Such a hybrid definition of form shapes his 1805 "Essay on the Geography of Plants": "It is in the absolute beauty of forms, in harmony and contrast, that the assemblages are created of what we call the 'natural character' of this or 
that region." 37 Humboldt's Kosmos, written in 1843-44 and published in 1845, directly imports the word Lebensform into an accounting of the nonhuman world; he writes of "die microscopischen Lebensformen des Südpol Meeres" (the microscopic life-forms of the Antarctic seas). ${ }^{38}$ Humboldt influenced the thinking of Charles Darwin, who read Humboldt on his voyage on the Beagle and took to heart Humboldt's conception of the environmental shaping of form.

Ernst Haeckel in 1866 and 1868 used Lebensform in a broad biological sense, while maintaining Wilhelm von Humboldt's use of the term to refer to custom, in Generelle Morphologie der Organismen (General Morphology of Organisms) and Natürliche Schöpfungsgeschichte (The History of Creation): "This differentiation or separation, this continually increasing divergence of the human character and human life form expresses itself by the ever more pronounced and ongoing division of labor for individuals [Diese Differenzirung oder Sonderung, diese stetig zunehmende Divergenz des menschlichen Charakters und der menschlichen Lebensform wird hervorgebracht durch die immer weiter gehende und tiefer greifende Arbeitstheilung der Individuen]."39 In Morphologie, considered Haeckel's theoretical masterpiece, he wrote: "All life forms, even the highest and most complex among them, can arise only by this means-through gradual differentiation and transmutations of the simplest and lowest forms of existence." 40 These texts were hugely popular-Schöpfungsgeschichte went through twelve German editions and by World War I had exposed more readers to Darwinian theory than had Darwin's own books. ${ }^{41}$ Lebensform also shows up in Haeckel's 1899 Die Welträthsel (The Riddle of the Universe), though it always appears as "einzellige Lebensform" (single-celled life-form). "Forms of life" appears in a 1904 English adaptation of Haeckel's text, entitled The Wonders of Life. ${ }^{43}$ Haeckel, a student of Müller, was an admirer of Goethe's aesthetic theory of morphology, but he fused it with a Darwinian commitment to the notion of natural selection as the sculptor of form-indeed, Haeckel dedicated the second volume of Generelle Morphologie to Darwin, Goethe, and Jean-Baptiste Lamarck, the "three founders of descent theory." ${ }^{44}$ Haeckel faulted Darwin, however, for focusing overmuch on inorganic environmental determinants of form and for attending insufficiently to the ways living things shaped one another: "In order to comprehend truly the tremendous importance that the struggle for existence possesses for the formation of the entire organic nature . . . one must not conceptually extract the particular lifeforms and merely observe them. . . . Rather one must compare these lifeforms in their collective entirety." 45 Insofar as Haeckel retained something of Goethe's intuition about archetypes, he sited those archetypes not in an ideal world, but in the past. His dictum that "ontogeny recapitulates phylogeny" located archetypes in a kind of evolutionary memory. ${ }^{46}$ Haeckel's 
elaborate lithographs of radiolaria—which he termed "art forms in nature"suggest a secondary meaning of form referring to the precision and geometrical discipline he discerned in the organisms he illustrated. ${ }^{47}$

\section{Life-Forms: \\ The Induction of Living Form}

During the mid-nineteenth century, life form became increasingly common in English. The earliest published instance of life form we have been able to find appeared in 1844 in the New Age, Concordium Gazette, and Temperance Advocate, where it was used not in the context of biology, but to refer to studies of animal magnetism: "The Magnetist looks to the scriptures for confirmation for all that he advances when he says that the Deity is working three organizations - the physical organism, the intellectual organism, and the Divine organism; and again, when he declares that the physical Life form has its senses, the Light intellectual form has its clairvoyance, and the Divine Love form its conscientious sensibility." 48 However, life forms does not enter common parlance for two more decades, after which it begins to be used regularly in journals such as the American Naturalist, where the word appeared in at least eleven separate articles between 1878 and 1898. An early use of life form in English comes in 1869 in the Anthropological Review: "But geology bears unflinching witness to the fact, that the progression of life forms has not taken place by consecutive steps of ascent." ${ }^{\text {"9 }}$ Indeed, there are many appearances of life form or life-form prior to the OED's 1899 mention. In these instances, life form almost always is embedded in an account of descent with modification. Charles Darwin's theory of evolution through natural selection is the overwhelming frame of reference. ${ }^{50}$

Allied terms circulated during Victorian arguments over the nature of geological and biological change prior to the publication of Darwin's On the Origin of Species, in which participants debated the merits of uniformitarianism, catastrophism, and transformism. In such discussions, forms of life referenced extant and extinct organic forms, pointing toward as-yet undiscovered fossilized forms of life and (in early examples of abductive biological thinking) even future or imagined organisms. ${ }^{51}$ Though Victorian thinkers did not use life forms, forms of life was common, and it suggests a similar conceptual niche in which life references its own limits. ${ }^{52}$ The capaciousness of forms of life served especially well those arguing for the possible limitless plenitude of living things, and for those speculating on processes that generated biological forms and their transmutations. In his Vestiges of the Natural History of Creation, Robert Chambers in 1844 uses "forms of life" and "organic forms" to speak to the diversity of biological matter, both in current and earlier eras: "These facts clearly show how all the various organic forms of our world are 
bound up in one-how a fundamental unity pervades and embraces them all, collecting them, from the humblest lichen up to the highest mammifer, in one system." ${ }^{, 53}$ Geologist Adam Sedgwick, who was one of the most forceful detractors of Vestiges, countered that the hypothesis "that the animal kingdom, including both the extinct and living forms of life, might be arranged in some preconceived order of natural development" was "but a physical romance, and a work of imagination" lacking any "base in true induction." 54

Between the publication of Chambers's Vestiges and Darwin's Origin raged the "plurality of worlds" debate over the possibility of intelligent extraterrestrial life. Both sides of the argument deployed "forms of life" in reasoning about the limits of biology-and reached opposite conclusions. William Whewell, a liberal Anglican and prominent Victorian scholar best known for coining the term "scientist" in 1833, maintained that life did not exist on other planets; he considered his position both a scientific and a moral one. A vocal proponent of Baconian induction, Whewell believed that gleaning general principles from particulars was a means of discerning how God's laws governed nature. Belief in extraterrestrial life, Whewell contended, required that "[we] reject the laws which govern the known forms of life, in order that we may be able to maintain the possibility of some unknown form in a different planet. ${ }^{\text {} 55}$ To illustrate the dubiousness of suspending the laws discovered to determine known terrestrial biological adaptations, he fabulated conscious vaporous creatures populating the surface of Saturn (an abductive move that, as we will see, will be just fine with astrobiologists reasoning from as-yet unknown but possible cases).

Scottish evangelical David Brewster argued acrimoniously against Whewell, in favor of biological plenitude. For him, the diversity of life on Earth, and the voluminousness of space, pointed to the existence of intelligent life elsewhere. ${ }^{56}$ He suggested that the application of comparative anatomist Richard Owen's theory of vertebrate archetypes to "the possible forms of life in other planets possesses a more general interest, and forms an entirely new, and we think, irresistible argument for a plurality of worlds. ${ }^{, 57}$ The following year, a Unitarian divine elbowed his way into the debate in a series of lectures titled Astro-Theology, in which he speculated: "While the grand analogy is unbroken, inasmuch as gravitation, light and heat act by universal laws, the intensity varying in a known ratio to distance; that varied distance itself changes the result so greatly, as to forbid us to adhere too closely to the definite forms of life with which we are familiar on this Earth, in our reverent attempt to people those distant orbs. ${ }^{" 58}$ In such arguments, the conceptual elasticity of "forms of life" allowed Chambers, Whewell, and Brewster to designate the conceptual category of life even as their referents outpaced themselves. In the twentieth century, life forms would again be tuned to the fantastic and fanciful morphologies creatures might obtain on worlds other than this one. 
In 1878, British behavioral psychologist C. Lloyd Morgan wrote, "It is enough to state that it is almost universally believed by those competent to give an opinion, that all life forms have come into being by a process of evolution from primitive organic germs." ${ }^{59}$ Morgan was a student of T. H. Huxley, who also had a fondness for the term life-form, which appears several times in his essays. In his "Address of the President of the Geological Society" in 1870, Huxley mentions "our knowledge of paleozoic rocks and the lifeforms which they contain." ${ }^{\prime 60}$ It is notable that Huxley was fluent in German, having translated German vital materialist Karl Ernst von Baer into English.

How did Lebensform make it into English as life-form or life form? It is possible that Louis Agassiz, who worked with Müller and wrote in German, English, French, and Latin, may have imported Lebensform as life-form to the United States or at least popularized it there. Agassiz, whose scientific approach was influenced by the Naturphilosophie in which he had trained, moved to the United States in 1846, after having studied in Germany and France with Müller, Humboldt, and Georges Cuvier. Alpheus Packard, Agassiz's student and fellow scientist at the Museum of Comparative Zoology at Harvard University, used life-forms in 1885: "There is a strange commingling of life-forms in the Straits of Belle Isle," and also in 1888 (albeit then unhyphenated), arguing against the theory of natural selection: "This point is one which the writer has also made ... holding that it is an important objection to the theory of natural selection, the very nature of which involves the existence of a world already stocked with life forms. " ${ }^{\text {11 }}$ Writing about Agassiz in The American Naturalist (a journal Packard edited) at the close of the nineteenth century, Packard describes Agassiz's theory of "embryonic," "synthetic," and "prophetic" types of organisms, twice using life-forms to describe his mentor's work. ${ }^{62}$ In Agassiz's Contributions to the Natural History of the United States of America, life-form does not appear, but is nonetheless implied: "The combination, in many extinct types, of characters which, in later ages, appear disconnected in different types, exhibits thought, prophetic thought, foresight; combinations of thought preceding their manifestation in living forms." ${ }^{63}$ This is exactly the position against which Darwin argued; life forms were not expressions of an abstract archetype and certainly not emergent from an internal teleological force; rather, any such archetype as there might be was a material ancestor. Robert Richards writes, "The generalized archetype of the vertebrates did not lie hidden away as an idea in the mind of God; rather, it was the form of a creature that walked the earth many generations ago." ${ }^{64}$ Darwin argued inductively (though speculatively), from data he and others collected, that a process of descent with modification could be inferred as the force giving form to organisms-form that was transmitted down generations. In Origin, Darwin writes of the "general succession in the forms of life." ${ }^{65}$ At the end of the first edition of Origin, though, he writes that, "probably all the 
organic beings which have ever lived on this earth have descended from some one primordial form, into which life was first breathed," a phrasing that permits readers to imagine material form as separate from a life force. ${ }^{66}$

The reader will have noticed that English life form appears in two ways, with and without the hyphen: life-forms and life forms. Life-form, with hyphen, may be an attempt to preserve the word's German origin. But life-form also, by the opening of the twentieth century, begins to have a specific meaning in botany (as, recall, a classification "based upon the position of the buds relative to the soil surface during the unfavourable season" $[O E D]$ ). Christen Raunkiær's technical meaning of life-form is still in strong use in botany-and employed a good deal in invasion biology, to fix on the adaptational reproductive characteristics of invasive, or "alien," species, keeping alive the biogeographic meaning pioneered by Humboldt. The OED credits Raunkiær with bringing life-form into common usage, despite the fact that Lebensform and life-form had been in use for about one hundred years and fifty years, respectively, at the time that Raunkiær published Planterigets Livsformer og deres Betydning for Geografien. ${ }^{67}$ Nonetheless, the primary botanical sense of life-form as it is used today is associated with the ideas of Raunkiær on the relation of plants to their environments, which he first presented in 1903 at a meeting of the Danish Botanical Society. ${ }^{68}$ Raunkiær owed much of his theory of life-forms to Alexander von Humboldt, whom he credited in the French translation of his article for his phytogeographic theory, in which a plant acts as "the recorder of the biological value of any climate." 69

Once imported from German into English, life-form loses, along with its hyphen (which it consistently retains only in botany), much of the reference to deductive reasoning that had accompanied it when deployed in teleo-mechanist discourse and other circles of German Romanticism. As life comes to modify form, rather than being designated by form's self-generation, life form becomes the subject of Darwinian attention, and form refers to particular arrangements and shapes of living things. And, interestingly, life form, without hyphen, permits "life" and "form" to work as independent concepts. Where, for Darwin, the forms at stake in his theory of evolution were species, the phytogeographic life-forms of Humboldt and later of Raunkiær were anchored in particular habits, not, as with Darwin's species, their genealogy or phylogeny. The "form" of life-whether apprehended as materializing in species (durable but changeable genealogical kinds) or as sorted into types occupying spaces of physical, metabolic, or ecological possibility (for example, photosynthesizers, deep-sea dwellers) - thus crystallizes with respect to different kinds of causal ontologies, different fields of possibility. Indeed, we will show in the next section how in the twentieth century possibility is amplified to become itself an object of theory; life forms not as archetypes, but future types. 


\section{"Life Forms, Wherever They Are": The Abduction of Living Form}

The objects and phenomena to which the notion of the life form refers are framed by conceptual commitments. Darwin's theory of evolution by natural selection, for example, offered an account of how living form materialized out of what we would now call environmental or ecological dynamics. In the twentieth century, a variety of attempts to expand biological theory sought to amplify explanations of living form by locating such accounts in the more universal territories of physics, chemistry, and mathematics. ${ }^{70}$ While such forays into what came to be called "theoretical biology" never fully reformatted the dominant, empirical, and experimental tradition of biology, they bring into relief how the form in life forms came to be epistemologically extended into the realm of the conjectural. Theoretical biology can help us understand the ampleness of the "any" in the OED's second definition of life-form, "any living thing" (and we write here of that genre of theoretical biology in dialogue with physics, chemistry, and geometry rather than of those versions occupied with mathematical models of population genetics, sex ratios, or selection) ${ }^{71}$ Together with science fiction-fueled speculations about life on other worlds-about which more in a moment-theoretical biology marks out the ways that form came unmoored from life, as the two words, having lost their corseting hyphen, began circulating independently of each other. Indeed, theoretical biologists rarely-if ever-mention life forms at all, choosing instead to refer merely to form, which is often used interchangeably with organization, morphology, and pattern. The concept of life form has subsequently been generalized to include purely theoretical, even fictional, instances.

Theoretical biology is generally understood to have begun with the work of D'Arcy Thompson in On Growth and Form, from 1917. Thompson argued that the shape of organisms was both constrained and shaped by physics, by a mathematics or geometry of nature; embryology might learn much from studying crystal growth patterns. The forces of natural selection and mutation alone could not account for the diversity and unity of forms of living things. Thompson wrote of "mechanical phenomena which are profoundly associated with Life, and inseparable from our understanding of Growth and Form" and urged that organisms be understood as objects, writing that "the form of an object is a "diagram of forces." "72 Developmental biologist John Tyler Bonner writes that Thompson "showed that to a remarkable degree the form of animals and plants could be described in physical and mathematical terms; nature subscribed to the sound principles of engineering." As Evelyn Fox Keller summarizes the matter, Thompson thought that "families of animal forces are bound by an underlying algebraic structure." 
In the end, Thompson was less concerned with the empirical world than with the logic behind it—and, indeed, with what that logic might predict. He wrote less of the empirical than about what was, in his words, "theoretically imaginable." 75

Thompson had many successors, biologists who trained less attention on selection and heredity and more on the manifestation of organic bodies with respect to the physics of the world. In 1957 C. H. Waddington wrote of "epigenetic landscapes," representations of the space of possibility for organismic embodiment, spaces occupied and realized when genotype is translated into phenotype. Life form, in this moment, lost its anchor in living material, such that living form came to be interpreted as just one instantiation of form more generally. Inquiring as to the essential mechanism driving morphogenesis at the 1968 symposium "Towards a Theoretical Biology" he had organized, Waddington provocatively contended that the question of form in biology had been given undue importance "because of a confusion between some of the numerous contexts in biology in which that very general word 'form' is used": "If one could discover a 'secret' of form, that would have a good claim to be one of the secrets of life, and a major one at that; whereas if form arises by quite different processes in different instances, can it really be so fundamental after all?" ${ }^{\prime 6}$ Form, in this moment, becomes programmatic: it is a formalism describing the mechanisms by which biological structure is generated, often conceived, after the rise of the genetic code, as purely informatic. As such, form comes to be only conceptually useful as far as it is predictive: Waddington largely dismisses form because "in all realms other than the molecular, biological forms seem to me to originate as consequences of biological activities, rather than being primary causes of them." 77

Between the 1970s and the 1990s, theoretical biologists of different stripes struggled to provide a universal account of life premised on self-organized form. Francisco Varela and Humberto Maturana's 1974 theory of "autopoiesis" saw the key to organismic integrity and form in the dynamics of self-organization. ${ }^{78}$ Developmental biologist Brian Goodwin, in such works as 1994's How the Leopard Changed Its Spots, sought to get at the question of "why life is capable of such diversity and beauty of forms while at the same time revealing an underlying unity."79 Reviving the spirit of Thompson, Goodwin argued that "organisms can take any form, have any color, and eat any food, subject only to very broad constraints that are basically due to physical and chemical laws." ${ }^{80}$ Goodwin maintained that organisms are "irreducible entities that are engaged in the process of generating forms and transforming them by means of their particular qualities of action and agency, or their causal powers." Earlier in the book Goodwin writes, "Organisms express their natures through the particular qualities of their form in space and time." cal biologist Stuart Kauffman, in The Origins of Order, wrote that scientists 
must ask "whether the morphologies of organisms to some extent represent the 'self-organized,' or natural, forms readily constructed via known developmental mechanisms." ${ }^{82}$ All of these writers wonder if biological theories of form can be grounded in a more universal, less contingent process-and whether biology might thereby become a more universal science.

The apotheosis of such a universalistic approach can be found in the computer-simulation driven field of Artificial Life. ${ }^{83}$ Founder Chris Langton claimed that Artificial Life is about "the attempt to abstract the logical form of life in different material forms," a definition that holds that formal and material properties can be usefully partitioned, and that what matters is form. ${ }^{84}$ Langton's declaration that life "is a property of the organization of matter, rather than a property of matter itself" offers an extreme Platonism that opens up the possibility that life might manifest in any material at all, anywhere, including cyberspace. ${ }^{85}$ Langton makes the abductive quality of this kind of reasoning explicit when he says, "It's very difficult to build general theories about what life would be like anywhere in the universe and whatever it was made out of, when all we have to study is the unique example of life that exists here on Earth. So, what we have to do-perhaps-is the next best thing, which is to create far simpler systems in our computers." ${ }^{86}$ Continuing in the same vein, Langton merges abduction and construction, claiming that "since it is quite unlikely that alien life forms will present themselves to us for study in the near future, our only option is to try to create alternative life-forms ourselves. ${ }^{" 87}$ Langton, trained as a physicist (and holding an undergraduate degree in anthropology), emblematizes the move in twentieth-century biology toward attempts to create a grand theoretical frame for biology, a frame that can be true, just as physics is supposed to be, anywhere in the universe. It is that universalism, in which life reaches toward forms as yet unencountered, that permits today's astrobiologists to extend the concept of life forms into the unknown, to seek out life forms, as the National Research Council has it, "Wherever They Are." It is this same openended deferral of meaning that renders the concept of life forms so generative for science fiction writers.

An influential and epistemologically diagnostic genre of writing in which the form in life form has been universalized, then, is science fiction. The Science Fiction Citation project of the OED contains quotations going back to 1931, notably, from Amazing Stories, "I have thought of it at length. It is disgusting. Compelled to traffic with an alien form of life!" 88 An earlier use of life-form in science fiction can be found in H. P. Lovecraft's 1929 short story, "The Dunwich Horror," which describes the body of the "teratologically fabulous" teenager, Wilbur Whateley: "It could not be vividly visualized by anyone whose ideas of aspect and contour are too closely bound up with the common life-forms of this planet and of the three known dimensions." 89 
This use of life-form in science fiction combines the aesthetic, morphological uses of the term- "ideas of aspect and contour"-with notions of life as materializing in physical spaces of possibility ("the three known dimensions"). Life form in twentieth-century science fiction has since become so commonplace as to risk cliché. The term appears multiple times in the stories of science fiction novelists Douglas Adams, Ursula K. Le Guin, and Philip K. Dick, even making an appearance in a variant of the classic Star Trek prologue in the film Star Trek II: The Wrath of Khan, summarizing the starship Enterprise's “ongoing mission: to explore strange new worlds, to seek out new life forms and new civilizations." ${ }^{90}$ Science fiction uses resonate with that of the National Research Council that opened our essay, in which Humboldtian concerns with materiality (now less about phytogeography than about the sorts of solvents in which life might thrive) fuse with Lovecraftian musings about aesthetic, transdimensional possibility.

\section{Coda:}

\section{The Construction of Living Form}

The latest research on life forms is no longer simply deductive, inductive, or abductive. Rather, it adds an element that we may describe as constructive. Scientists in the recently chartered field of synthetic biology seek to build biological parts that can be assembled into complex biological devices and systems. They justify their attempt to rebuild living systems from scratch using two arguments: that life may be made "better" through its redesign according to engineering principles, and that life itself may be better understood by fabricating viable systems de novo than by observing readymade living systems. ${ }^{91}$ The earliest use of life form we have been able to find in connection with synthetic biology comes in 2004, the year of the first synthetic biology conference, held at the Massachusetts Institute of Technology. That usage appears in a 2004 quotation from J. Craig Venter in Science: "'We'd like to be building life forms from first principles,' says Venter, 'but it's kind of hard when you don't know all the first principles." ${ }^{92}$ Much of synthetic biology is future oriented, abductively anticipating what sorts of things could theoretically be fabricated in the near future, once first principles are known: news reports announce "Synthetic DNA on the Brink of Yielding New Life Forms," and bloggers declare (abductively) that "synthetic biologists are the people who are going to build new life forms." ${ }^{\text {" T3 }}$ "That "life" in this field is treated as a coherent entity, despite the fact that what is at stake is its material reconstruction, attests to the capaciousness of the concept of life form to designate conjectural possibilities that nonetheless stabilize present kinds. 
How can we understand the life of form in the trajectory we have traced here? A recent issue of Representations, devoted to the question of form and formalisms-primarily as a concern in literary analysis, cultural history, and aesthetics—can provide a starting point. As Thomas Laqueur suggests in his piece "Form in Ashes" in that issue, at stake in discussions of form are questions about how to approach comparison across cases and how to find commensurability and calibration across realms of discourse and practice. Formalist approaches, he argues further, have often sought to pin down isomorphisms: "an 'identity' or 'similarity' or 'exact correspondence' or 'close relationship' of form between seemingly different contemporaneous or temporally distant domains." Laqueur points out that the term isomorphism "comes from chemistry and geology," in which "different but isomorphic substances crystallize in the same 'form,' or from mathematics, where isomorphism describes the identity 'of form . . . between two or more groups,' thereby authorizing certain operations." ${ }^{94}$ Laqueur names Max Weber's claim of an elective affinity between Calvinist Protestantism and capitalism as an operation animated by-authorized by-an argument of isomorphism. What operations are authorized by the isomorphisms assumed and set in place by the term life form? The primary operation, of course, is generalization-that disparate living things share form as such. More grandly, the claim of isomorphism across diverse biological entities authorizes the attempt to craft an encompassing theory of the biological, one that can be employed to abduct or construct new kinds.

\section{Notes}

For commentary and suggestions, we thank Jürgen Fauth, Gisbert Helmreich, Sarah Jansen, David Jones, Evelyn Fox Keller, Hannah Landecker, Tim Lenoir, Vincent-Antonin Lépinay, Rob Mitchell, Heather Paxson, Christian Reiss, Henning Schmidgen, Hillel Schwartz, Joan Steigerwald, Alma Steingart, and Martin Weiss. We also thank the readers of the Representations editorial board.

1. Committee on the Limits of Organic Life in Planetary Systems and Committee on the Origins and Evolution of Life, National Research Council, The Limits of Organic Life in Planetary Systems (Washington, DC, 2007).

2. Ibid., viii.

3. Henri Focillon, The Life of Forms in Art (1934) (Cambridge, MA, 1989), 34.

4. Charles S. Peirce, The Essential Peirce: Selected Philosophical Writings, Volume 2 (1893-1913), ed. Peirce Edition Project (Bloomington, 1998), 299. See also Richard Doyle, Wetwares: Experiments in Postvital Living (Minneapolis, 2003), 25.

5. Raymond Williams, Keywords: A Vocabulary of Culture and Society (Oxford, 1976), 15. 
6. Stefan Helmreich, Silicon Second Nature: Culturing Artificial Life in a Digital World (Berkeley, 1998), and Alien Ocean: Anthropological Voyages in Microbial Seas (Berkeley, 2009); Sophia Roosth, "Crafting Life: A Sensory Ethnography of Fabricated Biologies" (PhD diss., Massachusetts Institute of Technology, 2010).

7. The reader will note, for example, that we do not address the Aristotelian roots of notions of form in biology. While Aristotle's conception of living things as the result of the impressing of active masculine form onto passive feminine matter continues to haunt models of vitality, we hold, with Michel Foucault, The Order of Things: An Archaeology of the Human Sciences (New York, 1970), that "life itself" does not have independent epistemological or ontological status in ancient natural philosophy (this contra G. E. R. Lloyd, Science, Folklore, and Ideology: Studies in the Life Sciences in Ancient Greece [Cambridge, 1983]). For an account of the changing and multivalent semantics of life, see C. S. Lewis, "Life," in Studies in Words, 2nd ed. (Cambridge, 1990), 269-305, in which Lewis suggests that life is "a linguistic gadget, a tool whereby we can conveniently manipulate the subject matter of biology" (294).

8. Williams, Keywords, 19.

9. Ibid., 10 .

10. Quentin Skinner, "The Idea of a Cultural Lexicon," Essays in Criticism 29, no. 3 (1979): 205-24, and William Empson, "Compacted Doctrines," New York Review of Books 24, no. 17 (1977): 21-22.

11. Skinner, "Idea," 207.

12. Our project has close kin relations with Tobias Cheung, "From the Organism of a Body to the Body of an Organism: Occurrence and Meaning of the Word 'Organism' from the Seventeenth to the Nineteenth Centuries," British Journal for the History of Science 39, no. 3 (2006): 319-39. Cheung charts how the word organism, which once referred to "a principle of order became a generic name for individuals as natural entities or living beings." His essay "retraces the exact dates of the first appearances of a key term in the life sciences and of its usage in different discursive settings" (319), and follows the lead of Georges Canguilhem and Rainer Specht, who "focused on key terms in academic disciplines to reconstruct epistemological shifts" (320).

13. Evelyn Fox Keller and Elisabeth A. Lloyd, eds., Keywords in Evolutionary Biology (Cambridge, MA, 1992), 4.

14. Empson, "Compacted Doctrines."

15. Alan Durant, "Raymond Williams's Keywords: Investigating Meanings 'Offered, Felt for, Tested, Confirmed, Asserted, Qualified, Changed,'” Critical Quarterly 48, no. 4 (2006): 1-26.

16. Oxford English Dictionary, 2nd ed., s.v. "life-form."

17. While we seek at every turn to find first and diagnostic uses of life form, we cannot hope to have ferreted out every instance. More, the reader will note that while we spend goodly space on the German Lebensform, once we move into the English life form, we do not continue tracing allied words in German, Danish, French, or other languages. While one may argue that English became the dominant tongue in biology from the nineteenth century on, tracking kindred terms in other languages would be instructive. With Raymond Williams, we note, "To do such comparative studies adequately would be an extraordinary international collaborative enterprise" (Keywords, 20).

18. While the earliest found use of Lebensform appears in the 1830s, analogous terms surface earlier, notably in the work of Charles Darwin's grandfather Erasmus 
Darwin, who in Zoonomia (London, 1794) and The Temple of Nature (London, 1803) used phrases such as "organic form," "animal form," "living forms," and "forms of life" to champion Linnaean taxonomy and enunciate his theories of evolutionary transformism; in those theories, sexual reproduction was the "chef d'oeuvre, the masterpiece of nature" that drove transmissible modifications in morphology; Erasmus Darwin, quoted in Janet Browne, "Botany for Gentlemen: Erasmus Darwin and 'The Loves of the Plants,"' Isis 80, no. 4 (1989): 593-621, 603. Goethe and Schilling read Zoonomia in German translation. However, Erasmus Darwin's theory was properly neither deductive nor inductive, and in his writing he uses form to refer to external changes shaped by internal forces and irritations:

As life discordant elements arrests,

Rejects the noxious, and the pure digests;

Combines with Heat the fluctuating mass,

And gives a while solidity to gas;

Organic forms with chemic changes strive,

Live but to die, and die but to revive!

Immortal matter braves the transient storm,

Mounts from the wreck, unchanging but in form. (Temple, 22)

19. Karl Friedrich Burdach, Die Physiologie als Erfahrungwissenschaft, vol. 3 (1826-1840) (Leipzig, 1838), 721. Unless otherwise noted, all translations are our own.

20. A more Platonic world of ideal forms seems to be what novelist Christoph Wieland has in mind in his use of the word Lebensform in Aristipp und einige seiner Zeitgenossen (Leipzig, 1801): "Now, patterns of all possible life forms, animal or human, lay together in the lap of Lachesis [that one of the three fates who chooses life destinies for all beings], spread out upon the earth so that each could pick the most suitable [Nunmehr werden Muster aller möglichen Lebensformen, thierischer und menschlicher, die im Schooss der Lachesis beysammen lagen, auf der Erde vor ihnen ausgebreitet, damit jede diejenige wähle, die ihr am besten ansteht]" (260). Translation by Martin Weiss. In this account, Lebensform signals a space of possibility- "all possible life forms"within which life may materialize, informed not by the material world but rather preordained in some transcendent arena.

21. Karl Friedrich Burdach, Über die Aufgabe der Morphologie (Leipzig, 1817), quoted in Joan Steigerwald, "Goethe's Morphology: Urphänomene and Aesthetic Appraisal," Journal of the History of Biology 35, no. 2 (2002): 291-328, 318.

22. Burdach's and Goethe's morphology are not here meant to be representative of German Romantic biology or of Naturphilosophie in general. Friedrich Wilhelm Joseph Schelling and the Jena Romantic circle took a different approach to the study of living form. For them, form was merely the visible manifestation of life's inner forces-the product, not the productive impetus. Further, "the interconnected activity of fundamental forces that Schelling attempted to comprehend could not be made visible or objective in the manner of [Alexander von] Humboldt's or Goethe's portrayals of nature. Indeed, Schelling argued that knowledge of how nature is constructed from invisible forces was necessarily a speculative science"; Joan Steigerwald, "The Cultural Enframing of Nature: Environmental Histories during the Early German Romantic Period," Environment and History 6 (2000): 451-96, 481. For a history of the notion of form within 
German morphological research, see Lynn Nyhart, Biology Takes Form: Animal Morphology and the German Universities, 1800-1900 (Chicago, 1995), which argues that nineteenth-century anatomy and zoology cultivated distinct approaches to (animal) form largely because of the demands of distinctive disciplinary questions. Nyhart's story suggests that there were intellectual and institutional trends in morphology that stayed arrival at any fully general theory of living form.

Lebensform appears in the work of physician Karl Eberhard Schelling, a proponent of theories of animal magnetism and a student of Goethe and Johann Friedrich Blumenbach. He used Lebensform in a book based on a thesis he wrote under the direction of Carl Friedrich Kielmeyer, Über das Leben und seine Erscheinung (On Life and Its Manifestations) (Landshut, 1806):

Such a relative indifference between the inner and outer life form of a heavenly body exists, shown by the outer, which appears to us to be the common gravitation of all organic and in-organic bodies against a center; just as from the other perspective, the common centrifugal tendency, which expresses itself in the coherence of the organic and in-organic bodies. - But now, specific weight and coherence ... are the conditions by which the various bodies contribute to the expression of the outer life form of a heavenly body, or to the independent movement of a heavenly body. - Therefore, because they have inherited both conditions, the organic bodies must also contribute to the expression of the outer life form of a heavenly body. On the other hand, the exterior reflexes of life in nature must themselves contribute to the expression of the inner life form of the same [life], which is why in organic nature as well it must be possible to demonstrate a point at which the relative indifference of the inner and outer is reflected by the inner. This happens in perception [Anschauung], which is the expression of the inner life form of a heavenly body in the same way as independent movement is that of the outer. Namely, as long as the perception is non-judgmental and pure-objective [rein-objectiv], without interference of a subjectivity, it is equally the sensorium of outer and inner things in the interior, in the same way, on the other hand, as brute weight, which somewhat unthinkingly sweeps away with it the inner and outer reflexes of life. (44-45)

Karl Eberhard Schelling's differentiation of inner and outer life forms is indebted to his older brother, Friedrich, who distinguished between the product and production of form. But whereas Friedrich Wilhelm Joseph Schelling managed the problem of apprehending the inner force of a life form by referring to Kant's reflective judgment of organized bodies and to the formative act of the artist, Karl Eberhard Schelling here suggests that both inner and outer forms may be comprehended through objective perception, a claim more in line with Goethe's approach.

Philipp Franz Walther, a follower of Friedrich Wilhelm Joseph Schelling, gave the title "Von den Formen des Lebens" (On the Forms of Life) to a chapter of his Physiologie des Menschen mit durchgängiger Rücksicht auf die comparative Physiologie der Thiere (Physiology of Human Beings with General Consideration to the Comparative Physiology of Animals) (Landshut, 1808); the book treats reproduction, irritability, and sensibility in plants and animals. Franz Joseph Schelver, also a follower of Friedrich Wilhelm Joseph Schelling, in 1822 wrote Lebens-und Formgeschichte der Pflanzenwelt (History of Life and Form of the Plant World) referred to in Goethe's Die Schriften zur Naturwissenschaft (Writings on Natural Science), bd. 9, abt. 1:262-63. Thanks to Joan Steigerwald for this information. 
23. Timothy Lenoir, "Kant, Blumenbach, and Vital Materialism in German Biology," Isis 71, no. 1 (1980): 77-108, and Timothy Lenoir, "The Eternal Laws of Form: Morphotypes and the Conditions of Existence in Goethe's Biological Thought," in Goethe and the Sciences, ed. F. Amrine, F. J. Zucker, and H. Wheeler (Dordrecht, 1987), 17-28. See also James L. Larson, Interpreting Nature: The Science of Living Form from Linnaeus to Kant (Baltimore, 1994).

24. Joan Steigerwald, "Natural Purposes and the Reflecting Power of Judgment: The Problem of the Organism in Kant's Critical Philosophy," European Romantic Review 21, no. 3 (2010): 291-308.

25. Lenoir, "Kant," 77. See Johannes Müller, "Schlussbemerkungen über die Entwickelungsvariationen der thierischen and menschlichen Lebensformen auf der Erde," in Handbuch der Physiologie des Menschen für Vorlesungen (Coblenz, 1840), 768-78.

26. Evelyn Fox Keller, "Ecosystems, Organisms, and Machines," Bioscience 55, no. 12 (2005): 1069-74, 1070.

27. Steigerwald, "Goethe's Morphology," 292.

28. Ibid., 311.

29. Ibid., 308. Steigerwald differs from our interpretation and emphases here, arguing that the a priori at stake may be principles of judgment-the moorings of a transcendental idealism-rather than finally accessible archetypes. We thank Steigerwald for bearing with our sometimes heterodox readings.

30. Comparative anatomist Johann Friedrich Blumenbach's 1781 theory of the Bildungstrieb (building-drive) posited a formative impulse in organisms "responsible for reproduction, nourishment, and restoration of parts"; Robert J. Richards, The Romantic Conception of Life: Science and Philosophy in the Age of Goethe (Chicago, 2002), 219. Bildungstrieb was for Blumenbach "a teleological cause fully resident in nature"; Richards, Romantic Conception, 221, "a secondary cause yielding immediate effects and itself . . . the effect of some hidden primary cause" (277). Blumenbach imparted to his many students, including Alexander von Humboldt, Karl Friedrich Kielmeyer, and Gottfried Reinhold Treviranus, a morphologically inflected Kantian philosophy in which scientific observation and aesthetic judgment were often entangled; see Robert J. Richards, The Tragic Sense of Life: Ernst Haeckel and the Struggle over Evolutionary Thought (Chicago, 2008).

31. Theodor Ludwig Wilhelm Bischoff, "Über den Bau des Crocodil-Herzens, besonders von Crocodilus lucius," in Archiv für Anatomie, Physiologie und wissenschaftliche Medicin (Berlin, 1836), 10. Translation by Gisbert Helmreich.

32. Wilhelm von Humboldt, Alexander von Humboldt, and Karl Heinrich Brandes, Wilhelm von Humboldt's gesammelte Werke (Berlin, 1841), 529.

33. Historian of biology Joan Steigerwald (personal communication) writes that "the Historisches Wörterbuch der Philosophie (Historical Dictionary of Philosophy) focuses entirely on the psychological, religious, philosophical and social uses of Lebensform, starting with Friedrich Schleiermacher (Psychol. Sämtl. Werke [1835-64] 3:6, 334f), then W. Wundt (Ethik 1886, 135f), and then moving on to 20th century figures." This lineage of Lebensform takes us up to Ludwig Wittgenstein, who in his Philosophical Investigations (1953; reprint, New York, 1958) used Lebensform — always translated as "form of life" in English—to refer to a frame of reference within which linguistic action becomes meaningful.

34. Alexander von Humboldt, Essai sur la Géographie des Plantes (Paris, 1805). Translated by Francesca Kern and Philippe Janvier in Foundations of Biogeography: 
Classic Papers with Commentaries, ed. M. Lomolino, D. Sax, and J. Brown (Chicago, 2004), 54.

35. Richards, Romantic Conception, 519.

36. Ibid., 520; see also Joan Steigerwald, "Figuring Nature, Figuring the (Fe)male: The Frontispiece to Humboldt's Ideas Towards a Geography of Plants," in Figuring It Out: Science, Gender, and Visual Culture, ed. A. Shteir and B. Lightman (Lebanon, NH, 2006), on the relation of Humboldt's ideas of plant form to Goethe's.

37. Humboldt, quoted in Kern and Janvier, Foundations, 56. This sense of Lebensform conveys an intuition that what is being given form is matter. Lorenz Oken, a German Naturphilosoph who developed his theory of Physiophilosophie between 1802 and 1810, did not use Lebensformen in his work, but gestured toward something like it repeatedly in fleshing out his notion of Urschleim, the fundamental substance that gives body to organic form. For example, in an English translation by Alfred Tulk: "Every Organic has issued out of mucus, is naught but mucus under different forms. Every Organic is again soluble in mucus; by which naught is meant, than that the formed mucus becomes one devoid of form"; Lorenz Oken, Elements of Physiophilosophy (London, 1847), 185, "The first organic forms, whether plants or animals, emerged from the shallow parts of the sea" (186), "So also in the succeeding forms of animal life the animal capsule or uterus originates" (355), and finally, "We can only perceive the forms of nature, because they all reside in ourselves, because we can create them" (461). Goethe promoted Oken as a professor at the University of Jena and attended Oken's lectures, although Goethe and Oken's relationship soured when both took credit for the vertebral theory of the skull; Robert J. Richards, The Meaning of Evolution: The Morphological Construction and Ideological Reconstruction of Darwin's Theory (Chicago, 1993), 37. While writing Moby-Dick, Herman Melville read Oken's Elements of Physiophilosophy and inscribed a quotation from Oken's book on the flyleaf of a copy of Moby-Dick that he presented to a friend; see Jill Barnum, "Melville, Lorenz Oken, and Biology: Engaging the 'Long Now," Leviathan 7, no. 2 (October 1, 2005): 41-46, 44.

In Biology Takes Form, Lynn Nyhart writes that, "Despite its strangeness to us, [the] view of development as the crucial link between the underlying, ideal order of living nature and the particular real-world form of the individual organism provided a powerful set of assumptions for many life scientists in the first third or so of the nineteenth century, and continued to undergird the work of morphologists for decades thereafter" (43-44).

38. In the English edition of Kosmos, Lebensformen was translated as "animals," so it is unlikely that Lebensformen found its way into English from this Humboldt text. A term more associated with Humboldt than Lebensform was Wuchsform (growth form); see Alexander von Humboldt, Ideen zu einer Physiognomik der Gewächse (Stuttgart, 1806).

39. Ernst Heinrich Philipp August Haeckel, Natürliche Schöpfungsgeschichte: Gemeinverständliche wissenschaftliche (Berlin, 1868), 251, and Generelle Morphologie der Organismen (Berlin, 1866).

40. Quoted in William Coleman, Biology in the Nineteenth Century: Problems of Form, Function, and Transformation (Cambridge, 1977), 161.

41. Richards, Tragic Sense, xviii. 
42. Ernst Heinrich Philipp August Haeckel, Dei Welträthsel: Gemeinverständliche Studien über monistische Philosophie (Bonn, 1899).

43. Ernst Heinrich Philipp August Haeckel, The Wonders of Life: A Popular Study of Biological Philosophy, trans. Joseph McCabe (New York, 1904).

44. Quoted in Richards, Tragic Sense, 119.

45. Quoted in ibid., 143.

46. See Ruth Rinard, "The Problem of the Organic Individual: Ernst Haeckel and the Development of the Biogenetic Law," Journal of the History of Biology 14, no. 2 (1981): 249-75.

47. Haeckel's attention to symmetry, arrangement, and form strongly influenced Surrealist and Bauhaus artists, among them Max Ernst, Wassily Kandinsky, and Paul Klee. Klee wrote that "form is the end, death. Form-giving is movement, action. Form-giving is life"; quoted in Mitchell Whitelaw, Metacreation: Art and Artificial Life (Cambridge, MA, 2004), 15, and "Starting from nature, the students will perhaps arrive at their own forms, and one day be themselves nature, construct like nature"; quoted in Paul Rabinow, Marking Time: On the Anthropology of the Contemporary (Princeton, 2008), 101. See also David Brody, "Ernst Haeckel and the Microbial Baroque," Cabinet, no. 7 (Summer 2002): 25-27. Klee's demarcation of form and form-giving hearkens back to Schelling and the Jena Romantics, who believed that "nature, in both its inorganic and organic forms, is that 'middle' [das Mittel] between productivity and product, between the free and the fixed, the middle that is ever in a state of formation"; Steigerwald, "Cultural Enframing," 483. Schelling and the Jena Romantics further claimed that the artistic sensibility could succeed where rational observation failed, spanning the gulf between life's inner forces and outer manifestations by "comprehend [ing] how in natural products particular material is informed by a universal form" (484). The art connection suggests that another lineage for life form may be in life drawing. One touchstone for such a lineage may be Allan Harrison, "An Analysis of the Life-Form in Art," Transactions of the American Philosophical Society 15, no. 2 (1875): 279-350.

48. "Electro-Magnetism," New Age, Concordium Gazette, and Temperance Advocate 1, no. 16 (1844): 203-5, 204.

49. "Theories of Human Origin," Anthropological Review 7, no. 24 (1869): 18.

50. This is the case even if Darwin's theory is being argued against. In 1878, Alexander Wilford Hall, a Methodist minister from New York, published The Problem of Human Life: Embracing the "Evolution of Sound" and "Evolution Evolved" (New York), in which he argues against both Darwinian theory and the wave theory of sound; see M. C. M. Wright, "A Short History of Bad Acoustics," Journal of the Acoustical Society of America 120, no. 4 (2006): 1807-15. He wrote, "As the physical structure contains not only the different organs of the body but an almost infinite number and variety of separate molecules and units of real organic atoms, so the vital organism within each living creature contains not only the intrinsic life-form of the specific being it inhabits but is a veritable microcosm or a little universe of life-forms which include the intrinsic germs of all organic being [ sic] wherever found"; Hall, Problem of Human Life, 415. Such a notion of natural history, in which the earliest organism had all future organisms latent within it, is a throwback to earlier articulations of "evolution" by such figures as the Dutch insectologist Jan Swammerdam; Richards, Romantic Conception, 211. 
51. On the last day of 1853, Charles Dickens asked about organisms to come in his poem "New Year's Eve": "In the dark yet lustrous Future / What life-forms may be curl'd!”; Charles Dickens, "New Year's Eve," Household Words: A Weekly Journal 8 (London, 1854): 418.

52. The fact that Victorians routinely used forms of life and organic forms without once mentioning life-forms reinforces our supposition that the English term was translated from German, and that lebensformen and life-forms did not emerge independently of each other.

53. Robert Chambers, Vestiges of the Natural History of Creation (London, 1844), 149.

54. Adam Sedgwick, A Discourse on the Studies of the University of Cambridge, 2nd ed. (Cambridge, 1850), clviii-clix.

55. William Whewell, The Plurality of Worlds (Boston, 1855), 256.

56. John Hedley Brooke, "Natural Theology and the Plurality of Worlds: Observations on the Brewster-Whewell Debate," Annals of Science 34, no. 3 (1977): 221-86.

57. David Brewster, More Worlds Than One: The Creed of the Philosopher and the Hope of the Christian (London, 1854), 97.

58. Edward Higginson, Astro-Theology; or The Religion of Astronomy (London, 1855), 80-81. Higginson regularly uses "forms of life" in his lectures to refer to organisms yet to be discovered. For example: "Surely we do not doubt the possibility of countless other forms of life, besides those with which we are actually acquainted!" (81) and "The discriminating circumstances revealed through the recent wonderful improvements in the telescope, if they make it more difficult to conceive that certain globes in our system are inhabited by forms of life at all resembling those with which we are familiar, render it more difficult still to doubt it as regards those others which are proved to resemble our globe very nearly in the physical circumstances which specifically adapt it for human residence" (30).

59. C. Lloyd Morgan, "Physiography," American Naturalist 12, no. 10 (1878): 676.

60. Thomas Henry Huxley, The Scientific Memoirs of Thomas Henry Huxley, ed. Michael Foster and Edwin Ray Lankester (London, 1901), 3:521.

61. Alpheus S. Packard, "Life and Nature in Southern Labrador," American Naturalist 19, no. 3 (1885): 269-75, 270, and "On Certain Factors of Evolution," American Naturalist 22, no. 261 (1888): 808-21, 820.

62. Alpheus S. Packard, "The Philosophical Views of Agassiz," American Naturalist 32, no. 375 (1898): 159-64.

63. Louis Agassiz, Contributions to the Natural History of the United States of America (Boston, 1857), 1:134.

64. Richards, Romantic Conception, 532. Or, as Alfred Russel Wallace later argued, teleological forces acted on a multiplicity of possible life forms, rather than upon a single species. Wallace wrote in a letter to Arabella Buckley, Charles Lyell's secretary, in March 1909: "Another point I am becoming more and more impressed with is, a teleology of fundamental laws and forces rendering development of the infinity of life-forms possible (and certain) in place of the old teleology applied to the production of each species"; in James Marchant, Alfred Russel Wallace: Letters and Reminiscences (London, 1916), 2:89-90.

65. Charles Darwin, On the Origin of Species (1859) (Cambridge, MA, 1964), 328.

66. Ibid., 484. And see Gillian Beer, Darwin's Plots: Evolutionary Narrative in Darwin, George Eliot, and Nineteenth-Century Fiction, 2nd ed. (Cambridge, 2000), 48, for a discussion of how this rhetorical swerve may have been meant to satisfy creationist readers. We here leave to the side discussions of life and form emanating 
from particularly religious (often Christian) traditions, which, if our framing were slightly different, would be instructive to track. Jakob Böhme's 1621 De Signatura Rerum (The Signature of All Things), a religious treatise on morality, sees a moral signature installed in each person: "as the vital Signature, that is, as the Form of Life is figured in the Time of the Fiat at the Conception, even so is its natural Spirit"; Jakob Böhme, The Works of Jacob Behmen, The Teutonic Theosopher (London, 1781), 4:10. The presence of the divine in various strains of vitalism (e.g., in the thinking of Quaker mystic Anne Conway) may provide another history for the generation of ideas about life forms-one relevant to contemporary New Age appropriations of particularly astrobiological speculation.

67. Christen Raunkiær, Planterigets Livsformer og deres Betydning for Geografien (Copenhagen, 1907).

68. See William G. Smith, "Raunkiær's 'Life-Forms' and Statistical Methods," Journal of Ecology 1, no. 1 (1913): 16-26. Raunkiær subsequently published this work in Danish ("livsformen"), French ("types biologiques"), and German ("Lebensformen"). Livsformer appeared in Danish prior to Raunkiær, however. Its first use in a biological context was as early as 1877 , when C. J. Sehive wrote, "Boeck fremlagde Tegninger af mikroskopiske Organismer og gav en Udvikling angaaende disse elementaere Livsformer [Boeck presented drawings of microscopic organisms and suggested a developmental sequence for these elementary life-forms]"; Forhandlinger $i$ Videnskabs-Selskabet $i$ Christiania (Christiania, 1877). Translation by Miriam Zeitzen.

69. Quoted in Smith, "Raunkiær's 'Life-Forms,"” 16.

70. Exemplary of this shift in meaning is astrophysicist A. S. Eddington's fanciful 1928 rumination on Jovian and Martian ecologies, which begins: "It is idle to guess the forms that life might take in conditions differing from those of our planet. . . . To avoid endless conjecture I shall assume that the required conditions of habitability are not unlike those on the earth, and that if such conditions obtain life will automatically make its appearance"; A. S. Eddington, The Nature of the Physical World (London, 1928), 170.

71. See M. Mangel, ed., special issue, Classics of Theoretical Biology, part 1. Bulletin of Mathematical Biology 52, no. 1/2 (1990): 1-318.

72. D'Arcy Thompson, On Growth and Form (1917) (Cambridge, 1992), 5, 11. Thompson's work differed from that of his contemporary, French chemist Stéphane Leduc, who also sought to investigate similarities between the mechanics of physical things and organisms. Leduc believed that the abiotic generation of life forms at the nuclear level was possible through manipulating potassium nitrate, and that the making of life forms at the cellular level could be achieved through the proper play with metallic salts and alkaline silicates. He grew crystalline structures in the lab, "osmotic growths" he thought of as alive. According to Evelyn Fox Keller, Leduc "viewed the entire ensemble of functions that constitute life as itself 'conditioned by form, that is, the external, internal and molecular forms of the living being.' So extensive and so close were the resemblances he was able to observe that Leduc persuaded himself that here, in the forces of osmotic pressure, he had found the fundamental physical basis (or cause) of all life's most essential properties"; Evelyn Fox Keller, Making Sense of Life: Explaining Biological Development with Models, Metaphors, and Machines (Cambridge, MA, 2002), 28. Leduc's critics said that Leduc was confusing analogies with living form with a theory of living form, and, indeed, the very notion of form with life itself. 
73. Quoted in Keller, Making Sense, 64.

74. Ibid., 61. This vision was, in its way, Goetheian. Keller writes that for Thompson, form evoked "both the aesthetic notion of 'formal' and the mathematical notion of "formalism"' (54).

75. Thompson, On Growth and Form, 269.

76. C. H. Waddington, Towards a Theoretical Biology: An IUBS Symposium (Chicago, 1968), 109.

77. Ibid., 111.

78. Francisco Varela, Humberto Maturana, and R. Uribe, "Autopoiesis: The Organization of Living Systems, Its Characterization, and a Model," BioSystems 5 (1974): 187-96.

79. Brian Goodwin, How the Leopard Changed Its Spots: The Evolution of Complexity (New York, 1994), 78.

80. Ibid., 87 .

81. Ibid., 176, 19.

82. Stuart Kauffman, The Origins of Order: Self-Organization and Selection in Evolution (Oxford, 1993), 537.

83. See Doyle, Wetwares, 2003. For a review of concepts of "life" in primary and secondary literature on Artificial Life, see Stefan Helmreich, “'Life Is a Verb': Inflections of Artificial Life in Cultural Context," Artificial Life 13, no. 2 (2007): 189-201.

84. Quoted in Kevin Kelly, "Designing Perpetual Novelty: Selected Notes from the Second Artificial Life Conference," in Doing Science: The Reality Club, ed. John Brockman (New York, 1991), 1.

85. Chris Langton, “Toward Artificial Life," Whole Earth Review 58 (1988): 74-79, 74.

86. Quoted in Linda Feferman, Simple Rules ... Complex Behavior (video) (Santa Fe, NM, 1992). See also P. Prusinkiewicz and A. Lindenmeyer, The Algorithmic Beauty of Plants (Berlin, 1990).

87. Chris Langton, "What Is Artificial Life? The Digital Biology Project" (1994), available at http:/www.biota.org/papers/cglalife.html.

88. Science Fiction Citations, s.v. "alien life form," http://www.jessesword.com/sf/ view/12.

89. H. P. Lovecraft, The Best of H. P. Lovecraft: Bloodcurdling Tales of Horror and the Macabre (New York, 1987), 114. While this is the earliest use of "life form" in science fiction literature that we could identify, "form of life" did appear in Romantic and Victorian gothic fiction, as for example in Mary Shelley's 1837 Falkner: "To the surgeon's eye, a human body sometimes presents itself merely as a mass of bones, muscles, and arteries - though that human body may contain a soul to emulate Shakespeare-and thus there are moments when the wretched dissect the forms of life-and contemplating only the outward semblance of events, wonder how so much power of misery, or the reverse, resides in what is after all but sleeping or waking"; Mary Wollstonecraft Shelley, The Novels and Selected Works of Mary Shelley (London, 1996), 7:280-81, and Bram Stoker's Dracula (London, 1897): "Despises the meaner forms of life altogether, though he dreads being haunted by their souls" (272). A use of "life form" preceding its appearance in science fiction appears in the writings of late nineteenth- and early twentieth-century spiritualist Sir Arthur Conan Doyle. Doyle wrote about the coagulation of ectoplasm into anthropomorphisms: "It is conceivable that the thinner emanation of the clairvoyant would extend far further than the 
thick material ectoplasm, but have the same property of moulding itself into life, though the life forms would only be visible to the clairvoyant eye"; The Vital Message (New York, 1919), 150. Three years later, in 1922, Doyle would again employ the term, to speculate on the origin of fairies. He summarizes the theory of psychic researcher David Gow: "They are really life forms which have developed along some separate line of evolution, and which for some morphological reason have assumed human shape in the strange way in which Nature reproduces her types like the figures on the mandrake root or the frost ferns upon the window"; The Coming of the Fairies (Lincoln, NE, 2006), 148-49.

90. Gene Roddenberry, Harve Bennet, and Jack Sowards, Star Trek II: The Wrath of Khan (Hollywood, 1982).

From Douglas Adams, The Hitchhiker's Guide to the Galaxy (New York, 1979), 123: “'Oh God,' muttered Ford, slumped against a bulkhead. He started to count to ten. He was desperately worried that one day sentient life forms would forget how to do this. Only by counting could humans demonstrate their independence of computers."

Ursula K. Le Guin employs the acronym HILF- "high intelligence life forms"-in several of her novels and short stories, treating it as a category circumscribed both biologically and anthropologically. The titular protagonist of Rocannon's World is "a hilfer, an ethnologist of the High Intelligence Life Forms" (17), a sort of interstellar salvage ethnographer who carries the "Abridged Handy Pocket Guide to Intelligent Life-forms" (3). (Le Guin uses life form and life-form interchangeably.) Le Guin's almost Humboldtian use of life form as congruent with both custom and morphology is unsurprising, as Le Guin, daughter of anthropologist Alfred Kroeber, often draws upon the ethnographic genre. As she explained in an interview with the Guardian: "Claude Levi-Strauss has been a great source of fruitful irritation to my mind; so has Clifford Geertz"; "Chronicles of Earthsea" (2004), online at http:/ /www.guardian.co.uk/books/2004/feb/ 09/sciencefictionfantasyandhorror.ursulakleguin.

From Philip K. Dick, Galactic Pot-Healer (1969) (New York, 1994): “'What's a crumble?' he asked, when the robot monitor answered. . . .'On Rigel two it means a small life-form which scuttles_-" (19).

91. For sociological accounts of synthetic biology, see Alain Pottage, "Too Much Ownership: Bio-prospecting in the Age of Synthetic Biology," BioSocieties 1, no. 2 (2006): 137-58; Paul Rabinow, "Biopower, Dignity, and Synthetic Anthropos," posted 8 June 2009 on the National Humanities Center's On The Human forum, http:/ /onthehuman.org/2009/06/biopower-dignity-synthetic-anthropos/, and Adrian Mackenzie, "Design in Synthetic Biology," BioSocieties 5, no. 2 (2010): 180-98. An earlier practice traveling under the name synthetic biology came from Stéphane Leduc, who in 1912 published La Biologie Synthétique.

92. Dan Ferber, "Synthetic Biology: Microbes Made to Order," Science 303, no. 5655 (2004): 158-61, 161.

93. Rick Weiss, "Synthetic DNA on the Brink of Yielding New Life Forms," Washington Post, Monday, 17 December 2007, A01: and Annalee Newitz, "Mad Science Contest: Build a Lifeform and We'll Send You to Hong Kong or Give You \$1000" (2008), online at http://io9.com/5022316/mad-science-contest-builda-lifeform-and-well-send-you-to-hong-kong-or-give-you-1000.

94. Thomas Laqueur, "Form in Ashes," Representations 104 (Fall 2008): 50-72, 51. 